\title{
THE ASSESSMENT OF COMPANY PERFORMANCE USING BALANCE SCORECARD ANALYSIS
}

\author{
Sukmo Hadi Nugroho ${ }^{1}$, Elisabeth Tanti Pudiastuti ${ }^{2}$ \\ ${ }^{1}$ Universitas Esa Unggul Jakarta Indonesia \\ ${ }^{2}$ Sekolah Tinggi Manajemen STIMA IMMI Jakarta Indonesia
}

\begin{abstract}
Currently, the performance analysis of a company is the most needed thing in achieving the vision and mission of the organization. The purpose of this study is to determine the company's performance in terms of financial and non-financial performance using the Balanced Score Card approach through four perspectives, namely: (1) finance, (2) customers, (3) internal business, and (4) growth and learning. . The data collection method was done by qualitative and quantitative. The results of this study note that the performance of PT. Contractor Company Tbk, Tbk has been very good. From a financial perspective, it can be seen that the company's ability to guarantee short-term and long-term debt is quite good and the company's ability to get a good profit, as seen from the value of the Net profit margin. From the customer perspective, the results of the customer satisfaction survey are quite good. The level of employee satisfaction is quite good. As for the internal business, the effectiveness of the use of operating expenses was successfully realized by the company.
\end{abstract}

Keywords: Company Performance, Balance Score Card.

\section{INTRODUCTION.}

\section{$1.1 \quad$ Background}

In 2019 for PT. Contracting Company Tbk was a year full of dynamics from a macroeconomic and industrial perspective, marked by market fluctuations and increasing competition. During market changes and various challenges, the company was still able to record an increase in consolidated income, reaching a value of IDR 35.65 trillion, up $1.75 \%$ from the value of contractor services in 2018 , amounting to IDR 45.05 trillion. The company's net profit in 2019 decreased slightly by $2.1 \%$ to Rp 5.63 trillion from 5.85 trillion, so that the share profit also fell $6.5 \%$ to Rp 1,649 from the position of $R p 1,757$ in the previous year.

Based on the description above, it is interesting to examine the extent to which the level of success of the PT. Contractor Company Tbk using the Balanced Scorecard concept. The author is very interested in analyzing the performance of the company PT. Contractor Company Tbk because this company can survive during difficult situations and can even become a market leader in national contracting services.

The purpose of this study is to determine the performance of the company PT. Contractor Company Tbk is based on the Balanced Scorecard concept which includes financial perspectives, customers, internal business, as well as learning and growth at PT. Contractor Company Tbk.

\section{MATERIAL AND METHODS}

2.1. Company Performance

The term performance comes from the word job performance or actual performance. The definition of performance is the quality and quantity of work achieved by an employee in carrying out his duties following the responsibilities assigned to him (Mangkunegara, 2004). Company performance is something that is produced by the company in a certain period by referring to the established standards (Nugroho, 2019).

\subsection{Balance Scorecard}

The Balanced Scorecard is defined as a performance management tool that can help organizations translate their vision and strategy into action by utilizing a set of financial and non-financial indicators, all of which are interwoven in a causal relationship. Financial and non-financial indicators have four perspectives, namely: financial, customers, internal business, and growth and learning (Ahmadi, 2019).

\subsection{Previous Research}

Dina R. Gultom (2009), this research aims to know how the company's performance is measured by using the Balanced Scorecard approach at PT. Perkebunan Nusantara III (Persero) Medan. Research variables from financial, customer, internal business, learning, and growth perspectives. Research results of PT. Perkebunan Nusantara III (Persero) Medan has implemented the Balanced Scorecard approach in measuring its performance. 
Ahmad Falah Rusdiyanto (2010), the research objective was to determine the performance of the PDAM Semarang Regency using the Balanced Scorecard. Research variables: Financial Perspectives, Customers, Internal Business, Learning, and Growth. The results of this research show that the overall performance of the PDAM Semarang Regency is quite good, as indicated by the scorecard scores from each perspective. Sri Wahyuni (2011), the research objective was to determine the application of the Balanced Scorecard as a comprehensive and coherent analysis tool at PT. Semen Bosowa Maros, as well as to identify a description of the use of the Balanced Scorecard on performance appraisal at PT. Semen Bosowa Maros. Research variables from financial, customer, internal business, learning, and growth perspectives. The results of research performance at PT. Semen Bosowa Maros is good enough.

\subsection{Types of Research}

The research method used in this research is a combination of qualitative and quantitative research. The research method is a scientific way of obtaining data for specific purposes and uses. The scientific way means that research activities are based on scientific characteristics, namely rational, empirical, and systematic. Rational means that research activities are carried out in ways that make sense so that human reasoning can reach them. Empirical means that the ways that are done can be observed by the human senses so that other people can observe and know the methods used. Meanwhile, empirical means that the process used in the study uses certain steps that are logical (Sugiyono, 2004).

\subsection{Place and time of Research}

This research was conducted at PT. Contractor Company Tbk. The research time was carried out from August to October 2019.

\subsection{Population and Sample}

The population for this study was employees who were at PT. The Contractor Company Tbk and a sample of 150 employees are employees who live in the work location of the PT. Contractor Company Tbk.

\subsection{Method of collecting data}

The data collection method to obtain relevant and accurate data in this study is from a summary of the company's financial statements for 2017 to 2019 , in addition to conducting direct interviews and distributing questionnaires to employees of PT. Contracting Company Tbk.

\subsection{Data analysis Method}

This research uses quantitative data and qualitative data. In this study, each perspective in the Balanced Scorecard will be measured by different performance measurement indicators. The analysis used in measuring the four perspectives in the Balanced Scorecard, namely: financial perspective, customer perspective, internal business process perspective, and learning and growth perspective. From a financial perspective, it will be measured using the ratios contained in the company, such as liquidity ratios, solvency ratios, profitability ratios, and growth ratios. The level of market share control and the level of customer satisfaction are benchmarks from the customer perspective. Market share control by the company is seen from the level of increase in company sales from 2017 to 2019. From the perspective of internal business processes that will be considered are product innovation and the number of improvements made by the company to obtain quality products that are not less competitive with products offered by the company. competitors and the best service to customers. The learning and growth perspective is measured from the level of employee satisfaction.

\section{RESULT AND DISCUSSION}

\subsection{Financial Perspective Performance}

Performance measurement from a financial perspective in this study used the calculation of four financial ratios, namely the liquidity ratio, solvency ratio, profitability ratio, and growth ratio. The calculation of each ratio is as follows:

\subsubsection{Liquidity Ratio}

The liquidity ratio is an indicator of the company's ability to pay all short-term financial liabilities at maturity using available current assets (Bandono, 2019). Liquidity above is not only concerned with the overall financial condition of the company, but also with its ability to convert certain current assets into cash.

Table 1. Data of Current Ratio

\begin{tabular}{|c|c|c|c|}
\hline Year & Current Assets & Current Liabilities & Current Ratio \\
\hline 2017 & $22,048,115$ & $11,327,164$ & 1.95 \\
\hline 2018 & $27,814,126$ & $14,560,664$ & 1.91 \\
\hline 2019 & $33,579,799$ & $16,297,816$ & 2.06 \\
\hline
\end{tabular}

(In million Rupiah, except Current Ratio) Source: Processed Data, 2020 
In the results of the data processing above, the results obtained from 2017 to 2019 , the value of the current ratio is more than 1 , even close to the number 2, meaning that every 1 rupiah of current debt is guaranteed more than 1 rupiah. This shows that the ability of the current assets of PT Contracting Company Tbk guarantees almost 2 times the current liabilities. In terms of the current ratio, the financial condition of The Contracting Company Tbk is healthy.

Table 2. Data for Quick Ratio

\begin{tabular}{|c|c|c|c|c|}
\hline Year & Current Assets & Inventories & Current Liabilities & Quick Ratio \\
\hline 2017 & $22,048,115$ & $7,173,704$ & $11,327,164$ & 1.31 \\
\hline 2018 & $27,814,126$ & $6,176,470$ & $14,560,664$ & 1.49 \\
\hline 2019 & $33,579,799$ & $7,770,086$ & $16,297,816$ & 1.58 \\
\hline
\end{tabular}

(In million Rupiah, except Quick Ratio) Source: Processed Data, 2020.

The Quick Ratio from 2017 to 2019 has experienced a positive trend, namely having a ratio value that is always increasing. This means that $P T$
Contracting Company Tbk can guarantee its shortterm debt with more liquid assets.

Table 3. Data of Cash Ratio

\begin{tabular}{|c|l|c|c|}
\hline Year & \multicolumn{1}{|c|}{ Cash } & Current Liabilities & Cash Ratio \\
\hline 2017 & $3,995,265$ & $11,327,164$ & 0.35 \\
\hline 2018 & $7,935,870$ & $14,560,664$ & 0.55 \\
\hline 2019 & $10,059,803$ & $16,297,816$ & 0.62 \\
\hline
\end{tabular}

(In million Rupiah, except Cash Ratio) Source: Processed Data, 2020.

As with the quick ratio, each year the value of the cash ratio increases. From the results of the above calculation, it shows that every current debt of IDR 1 is guaranteed by cash assets of $35 \%$ in 2017 , $55 \%$ in 2018 , and $62 \%$ in 2019 .

\subsubsection{Solvency Ratio}

With this ratio, we can find out how the comparison of PT. Contracting Company Tbk's capital to loans from outside parties, as well as the ratio between total assets owned and loans from outside parties, the calculations are as follows:

Table 4. Data of Debt To Equity Ratio

\begin{tabular}{|c|c|c|c|}
\hline Year & Total Liabilities & Equity & DER \\
\hline 2017 & $18,000,076$ & $32,300,557$ & 0.56 \\
\hline 2018 & $21,713,346$ & $35,648,898$ & 0.61 \\
\hline 2019 & $21,715,297$ & $38,576,734$ & 0.56 \\
\hline
\end{tabular}

(In million Rupiah, except DER) Source: Processed Data, 2020.

From the calculation of the table above, PT. Contracting Company Tbk has its capital reserves that can guarantee its long-term debt with a stable value from 2017-2019. On average, every Rp. 1, - is guaranteed by 0.57 of the own capital owned by The Contracting Company Tbk.

Table 5. Data of Debt to Asset Ratio

\begin{tabular}{|c|c|c|c|}
\hline Year & Total Liabilities & Total Assets & Debt to Assets \\
\hline 2017 & $18,000,076$ & $50,300,633$ & 0.36 \\
\hline 2018 & $21,713,346$ & $57,362,244$ & 0.38 \\
\hline 2019 & $21,715,297$ & $60,292,031$ & 0.36 \\
\hline
\end{tabular}

(In million Rupiah, except Asset Ratio) Source: Processed Data, 2020.

The value of the debt-to-asset ratio is quite stable, around a ratio of 0.36 , meaning that The Contracting Company Tbk can guarantee Rp. 1 of its long-term debt with 0.36 of the total assets owned.

\subsubsection{Profitability Ratio}

By using this ratio, it can be seen how much PT. Contracting Company Tbk's ability to generate company profits. Here is the ratio in profitability: Gross profit margin. 
Table 6. Data of Gross Profit Margin

\begin{tabular}{|r|c|r|r|}
\hline Year & Gross Profit & Net Sales & G P M \\
\hline 2017 & $10,520,999$ & $55,953,915$ & $18.80 \%$ \\
\hline 2018 & $9,516,818$ & $51,012,385$ & $18.66 \%$ \\
\hline 2019 & $12,070,409$ & $53,141,768$ & $22.71 \%$ \\
\hline \multicolumn{3}{|r}{ Source: Processed Data, 2020 }
\end{tabular}

\subsection{Customer Perspective Performance}

Based on the results of the customer satisfaction survey at PT. Contracting Company Tbk, it can be seen that the customer satisfaction index has a score of 625 , this indicates that customers are at a good level of satisfaction with the services of The Contracting Company Tbk. Even though it is following the minimum target, which is in the 615 759 interval, the company must be able to improve service again so that customer satisfaction levels increase, namely at the highest interval of 760 904. The number of complaints received by PT. Contracting Company Tbk starting from 2018-2019 is as follows :

Table 7. Customer Complaint Acceptance Data

PT Contractor Company Tbk for the period 2017-2019

\begin{tabular}{|c|c|c|c|c|}
\hline \multirow[t]{2}{*}{ Note } & \multicolumn{3}{|c|}{ Years } & \multirow{2}{*}{$\begin{array}{c}\text { The increase - a } \\
\text { decrease }\end{array}$} \\
\hline & 2017 & 2018 & 2019 & \\
\hline Complaint Amount & - & 4058 & 3656 & $-11 \%$ \\
\hline
\end{tabular}

From the data above, it can be seen that PT. Contracting Company Tbk was able to reduce the number of customer complaints by $11 \%$, although the total complaints were still high and needed to be improved again in reducing the number of customer complaints (Reza, 2019).
3.3 Internal Business Process Performance

In the performance of internal business processes, the benchmarks used are innovation, after-sales service, and operational cost efficiency that has been carried out by PT. Contracting Company Tbk.

Table 8. Data on Operating Expenses against Operating Income PT Contractor Company Tbk for the period 2017-2019

\begin{tabular}{|l|c|c|c|}
\hline \multicolumn{1}{|c|}{ Note } & \multicolumn{3}{c|}{ Year } \\
\cline { 2 - 4 } & $\mathbf{2 0 1 7}$ & $\mathbf{2 0 1 8}$ & $\mathbf{2 0 1 9}$ \\
\hline Operating Expenses (Rp) & $27,270,787$ & $13,552,506$ & $15,805,029$ \\
\hline Operating Income (Rp) & $28,461,161$ & $19,856,255$ & $18,173,020$ \\
\hline $\begin{array}{l}\text { The ratio of Operating Expenses to Operating } \\
\text { Income (\%) }\end{array}$ & $96 \%$ & $68 \%$ & $87 \%$ \\
\hline
\end{tabular}

Source: Processed Data, 2020.

From the results of the above calculations, it can be seen that in 2017 the company's operating expenses were very high, indicated by a ratio value of $96 \%$ even though the operating income was quite large, this showed that the company had not been able to carry out cost efficiency arising from the company's operational activities. In 2018 operating expenses can be drastically reduced, indicated by a ratio value of $68 \%$ even though the amount of operating income has decreased from 2017, meaning that in 2018 the company was able to reduce operating costs so that the profit margins increased. In 2019 there was an increase in the ratio of operating expenses by $87 \%$ and operating income decreased less than in 2018. It can be concluded that the company succeeded in making operational cost efficiency in 2018.

\subsection{Learning and Growth Perspective Performance}

Performance measurement from a learning and growth perspective at PT. Contracting Company Tbk, measured using aspects of employee satisfaction and employee turnover. The employee satisfaction index obtained from distributing questionnaires is 1312 - 0 (invalid questions), then the total employee satisfaction index is 1312 , sothat employee satisfaction with the company is quite good. Employees agree or are between 1108 and 1368. 
Table 9. Measurement Results of Employee Turnover

\begin{tabular}{|l|c|c|c|}
\hline \multicolumn{1}{|c|}{ Note } & \multicolumn{3}{c|}{ Year } \\
\cline { 2 - 4 } & 2017 & 2018 & 2019 \\
\hline Total Employees (people) & 27,221 & 27,070 & 27,195 \\
\hline Number of Employees Left (person) & 720 & 1,370 & 1,018 \\
\hline Number of Employees Quitting (\%) & $2.6 \%$ & $5.1 \%$ & $3.7 \%$ \\
\hline
\end{tabular}

Source: Processed Data, 2020.

From the data above, it can be seen that the employee turnover rate at PT. Contracting Company Tbk is quite low, even though in 2018 there was an increase in the number of employees who quit by $5.1 \%$ and in 2019 it decreased to $3.7 \%$. This reflects that the company can maintain a good working environment for all its employee.

\subsection{Results of Measuring Company Performance with the Balanced Scorecard}

The following table is the result of performance measurement at PT. Contracting Company Tbk from four perspectives balanced scorecard.

Table 10. Results of Measurement of Company Performance with a Balanced Scorecard

\begin{tabular}{|c|c|c|c|c|}
\hline \multirow[t]{2}{*}{ Perspective } & \multicolumn{3}{|c|}{ Year } & \multirow[t]{2}{*}{ Average } \\
\hline & 2017 & 2018 & 2019 & \\
\hline \multicolumn{5}{|l|}{ Financial Perspective } \\
\hline \multicolumn{5}{|l|}{ a. Liquidity Ratio } \\
\hline - Current Ratio & 1.95 & 1.91 & 2.06 & 1.97 \\
\hline - Quick Ratio & 1.31 & 1.49 & 1.58 & 1.46 \\
\hline - Cash Ratio & 0.35 & 0.55 & 0.62 & 0.51 \\
\hline \multirow{2}{*}{\multicolumn{5}{|c|}{ b. Solvency Ratio }} \\
\hline & & & & \\
\hline - Total debt to equity ratio & 0.56 & 0.61 & 0.56 & 0.58 \\
\hline - Total debt to total asset ratio & 0.36 & 0.38 & 0.36 & 0.37 \\
\hline \multicolumn{5}{|l|}{ c. Profitability Ratio } \\
\hline - Gross profit margin & $18.80 \%$ & $18.68 \%$ & $22.71 \%$ & $20 \%$ \\
\hline - Net profit margin & $10.28 \%$ & $9.41 \%$ & $9.11 \%$ & $10 \%$ \\
\hline - ROI & $11.44 \%$ & $8.37 \%$ & $8.03 \%$ & $9 \%$ \\
\hline -ROE & $17.81 \%$ & $13.46 \%$ & $12.55 \%$ & $15 \%$ \\
\hline \multirow{2}{*}{\multicolumn{5}{|c|}{ Customer perspective }} \\
\hline & & & & \\
\hline - Customer satisfaction & - & $\cdot$ & 825 & 825 \\
\hline - Number of complaints & - & 4058 & 3656 & 3857 \\
\hline \multicolumn{5}{|l|}{ Internal business perspective } \\
\hline - Product innovation & - & - & - & \\
\hline -After-sale service & $\cdot$ & $\cdot$ & - & \\
\hline - Ratio of operating expenses to operating income & $96 \%$ & $68 \%$ & $87 \%$ & $84 \%$ \\
\hline \multicolumn{5}{|l|}{ Learning and growth perspective } \\
\hline - Employee satisfaction & - & - & 1312 & 1312 \\
\hline - Employee turnover & $2.60 \%$ & $5.10 \%$ & $3.70 \%$ & $4 \%$ \\
\hline
\end{tabular}

Source: Processed Data, 2020.

From the table above, it can be concluded that the performance of PT. Contracting Company Tbk has increased from the time between 2017 and 2019. From a financial perspective, the company's performance is very good, starting from the ability to guarantee the company's short and long-term debt.
Also, there was an increase in Gross profit margin from $18.80 \%$ to $22.71 \%$ in 2019 . From the customer perspective, seen from the customer satisfaction survey, it was at the satisfied level and the number of complaints decreased by $11 \%$ from 2018 . The internal business perspective shows an increase in 
cost efficiency operational in 2018 and decreased again in 2019. At the level of employee satisfaction at a satisfying level, it means that the company can maintain a comfortable work environment. Also, the number of employees who quit is only $4 \%$ of the total employees of The Contracting Company Tbk each year.

Although there are still some weaknesses, overall the performance of PT. Contracting Company Tbk can be said to be good. Of course, there are still many improvements that need to be done so that the company can remain competitive in the heavy equipment business and be able to maintain market share in the heavy equipment business. In the end, the use of the Balanced Scorecard can accommodate the needs of company management in assessing company performance both from a financial and non-financial side.

\section{CONCLUSION}

Based on the analysis of the results of the research and discussion, it can be concluded that the following are:

The ability of PT. Contracting Company Tbk to guarantee its short-term and long-term obligations is very adequate.

b. The company's profit from year to year (2017-2019) always increases, this proves that PT. Contracting Company Tbk can survive in a situation of economic fluctuation.

c. In terms of customers, PT. Contracting Company Tbk has high loyalty, as evidenced by the increasing number of customers and the number of company profits.

d. The working conditions of the employees of PT. Contracting Company Tbk has a conducive atmosphere, as evidenced by the survey.

e. Overall, the performance of PT. Contracting Company Tbk is very capable of experiencing fluctuating economic situations.

\section{FUTURE WORK}

Based on the conclusions and limitations of the research above, the suggestions put forward are as follows:

a. Companies should make comparisons with companies that have combined current assets with the best liabilities.

b. Companies should improve the efficiency of economic profitability so that operating profits will increase.

\section{ACKNOWLEDGEMENT}

The authors greatly acknowledge the support from Sekolah Tinggi Manajemen STIMA IMMI Jakarta and Universitas Esa Unggul Jakarta Indonesia for providing the necessary resources to carry out this research work. The authors are also grateful to the anonymous reviewers and journal editorial board for their many insightful comments, which have significantly improved this article.

\section{REFERENCES}

Ahmadi, \& Herdiawan, D. (2019). The application of CBA and SUG model for improving the quality of Indonesian navy human resources. International Journal of Recent Technology and Engineering, 8 (3), 393399.

https://doi.org/10.35940/ijrte.C4190.098319

Bandono, A. D. I., Suharyo, O. S., \& Riono. (2019). Applied fuzzy and NASA tlx method to measure of the mental workload. Journal of Theoretical and Applied Information Technology, 97(2), 476-489

Budiarti, Isniar. 2009. Pentingnya Pengukuran Kinerja Melalui Pendekatan Balanced Scorecard. Jurnal Profitabilitas. Vol. III, No. 1. Halaman 57-68.

Ciptani, Monika Kussetya. 2000. Balanced Scorecard sebagai Pengukuran Kinerja Masa Depan: Suatu Pengantar. Jurnal Akuntansi \&Keuangan. Vol. 2, No. 1. Halaman 21-35.

Gaspersz, Vincent. 2011. Sistem Manajemen Kinerja Terintegrasi Balanced Scorecard dengan Malcolm Baldrige dan Lean Six Sigma Supply Chain Management. Bogor: Vinchristo Publication.

Genny Luhung Prasojo, Supardji, Luthfiyah Nurlaela, Prasetyo Iswahyudi. (2020). ATTITUDES, ABILITIES, AND MOTIVATION ON THE PERFORMANCE ACHIEVEMENT OF FLIGHT INSTRUCTORS IN AKADEMI PENERBANG INDONESIA (API) BANYUWANGI. PalArch's Journal of Archaeology of Egypt / Egyptology, 17(7), 9637-9643.

Gultom, Dina R. 2009. Pengukuran Kinerja Perusahaan dengan Balanced Scorecard Studi Kasus pada PT. Perkebunan Nusantara III (Persero) Medan. Skripsi. Universitas Sumatera Utara. Medan. 
Haricahyo, D., Mubarok, A., Wibowo, U. L. N., \& Arif, R. (2020). PENGEMBANGAN PROFESIONALITAS GURU SESUAI TUNTUTAN REVITALISASI PENDIDIKAN VOKASI. SOSIOEDUKASI: JURNAL ILMIAH ILMU PENDIDIKAN DAN SOSIAL, 9(3), 233-236.

Hariri, A., Rusdiansyah, A., Mubarok, A., \& Arif, R. (2020). KAJIAN ASSESSMENT DAN EVALUASI PENDIDIKAN VOKASI PENGARUH SERVICE QUALITY TERHADAP STUDENT SATISFACTION PADA MAHASISWA TARUNA DIPLOMA 3 POLITEKNIK PENERBANGAN INDONESIA CURUG. SOSIOEDUKASI: JURNAL ILMIAH ILMU PENDIDIKAN DAN SOSIAL, 9(3), 237-243.

Jogiyanto. 2004. Metodologi Penelitian Bisnis, Salah Kaprah dan PengalamanPengalaman. Yogyakarta: BPFEYogyakarta.

Kusmayadi, Dedi. 2009. Pengukuran Kinerja dengan Balanced Scorecard: Kajian Teoritis dan Empiris. Jurnal Akuntansi FE Unsil. Vol. 4, No. 1. Halaman 536-543.

Luis, Suwardi dan Biromo, Prima. 2008. Step by Step in Cascading Balanced Scorecard to Functional Scorecards. Jakarta: Gramedia Pustaka Utama.

Mangkunegara, A.A. Anwar Prabu. 2004. Manajemen Sumber Daya Manusia Perusahaan. Bandung: Remaja Rosdakarya.

Mile, Yuldi. 2011. Pengaruh Perspektif Keuangan dan Pembelajaran terhadap Kinerja Manajer Perusahaan Asuransi. Jurnal Ekonomi Bisnis. Tahun 16, No. 1. Halaman 36-43.

Mulyadi. 2009. Sistem Terpadu Pengelolaan Kinerja Personel Berbasis Balanced scorecard. Yogyakarta: STIM YKPN.

Nugroho, S. H., Madhakomala, R., \& Gunawan, K. (2019). The system dynamic model for policy evaluation of navy personnel on the state-duty aspect. International Journal of Scientific and Technology Research, 8(12), 228-236.

Nugroho, S. H., Madhakomala, R., \& Gunawan, K. (2019). Analysis and scenario of navy performance allowance policy using system dynamic model. International Journal of Scientific and Technology Research, 8(12), 1140-1147.
Nugroho, S. H., Sukandari, B., Suharyo, O. S., \& Bandono, A. (2020). The application of NasaTlx methods to the analysis of Mtf navy personnel allocation. International Journal of Scientific and Technology Research, 9(3), 6172-6179.

Nany, dkk., 2008. Penerapan Balanced Scorecard sebagai Pengukur Kinerja Manajemen pada Rumah Sakit Umum Daerah Indramayu. Jurnal Riset Akuntansi dan Keuangan. Vol. 4, No. 1. Halaman 48-56.

Prasetiyatno, dkk., 2011. Pengukuran Kinerja Perusahaan dengan Metode Balanced Scorecard. Jurnal Performa. Vol. 10, No. 2. Halaman 71-82.

Pancawardani, Nurul Latifah. 2009. Pengukuran Kinerja Keuangan Perusahaan dengan Metode Analisa Cash Flow Ratio. Jurnal Fokus Ekonomi. Vol. 4, No. 2. Halaman 4659.

Prasetyo Iswahyudi, Dewie, T. W., Soedjarwo, S., \& Hartono, S. (2019). Influence of Graduation Quality and Flight Training as a Vocational School on International Standard Job Opportunities. TEM Journal, 8(4), 1456

Prasojo, G. L., Mubarok, A., Arif, R., \& Rusdiansyah, A. (2020). PENINGKATAN MUTU LULUSAN TARUNA AKADEMI PENERBANGAN INDONESIA BANYUWANGI DENGAN PERUBAHAN KEBIJAKAN KURIKULUM. SOSIOEDUKASI: JURNAL ILMIAH ILMU PENDIDIKAN DAN SOSIAL, 9(3), 271-279.

Reza, H. K., \& Nugroho, S. H. (2020). Relationship analysis of motivation and customer satisfaction on services quality aspect for online transportation. International Journal of Scientific and Technology Research, 9(4), 1101-1108.

Rinaldi, R., Mubarok, A., Putra, R. H., \& Pamandu, R. (2020). PENGGUNAAN METODE PEMBELAJARAN ACTIVE LEARNING DALAM MENINGKATKAN HASIL BELAJAR MOTIVASI MODEL ARCS. SOSIOEDUKASI: JURNAL ILMIAH ILMU PENDIDIKAN DAN SOSIAL, 9(3), 260-270.

Rivai, Veithzal dan Sagala, Ella Jauvani. 2009. Manajemen Sumber Daya Manusia untuk Perusahaan dari Teori ke Praktik. Jakarta: Raja Grafindo Persada. 
Rusdiyanto, Ahmad Falah. 2010. Analisis Kinerja dengan Pendekatan Balanced Scorecard pada PDAM Kabupaten Semarang. Skripsi. Universitas Diponegoro. Semarang.

Sugiyanto, Eko dan Anwar, Kasyful. 2003. Balanced Scorecard sebagai Sistem Manajemen Strategi. Jurnal Akuntansi dan Keuangan. Vol. 2, No. 1. Halaman 15-24.

Supriadi, Yoyon. 2017. Meningkatkan Profitabilitas Perusahaan melalui Manajemen Asset. Jurnal IImiah Kesatuan. Vol. 14, No. 1. Halaman 33-42.

Sapardianto. 2018. Analisis Pengukuran Kinerja Perusahaan dengan Konsep Balanced Scorecard (Studi Kasus pada PT Trustco Insan Mandiri Samarinda). eJournal Administrasi Bisnis. Vol. 1, No. 2. Halaman 94-103.

Sugiyono. 2004. Metode Penelitian Bisnis. Bandung: Alfabeta.

Suharli, Michell dan Laila, Erit. 2008. Studi Empiris terhadap Initial Return Awal: Aplikasi Balanced Scorecard pada Perusahaan Publik di Jakarta. Journal of Business Applied Management. Vol. 1, No. 1.

Halaman 77-91.

Sulung, S. D., Mubarok, A., Putra, R. H., \& Arif, R. (2020). IMPLEMENTASI MANAJEMEN MUTU DAN PENGARUHNYA TERHADAP PRESTASI SEKOLAH DI POLITEKNIK NEGERI BANYUWANGI. SOSIOEDUKASI: JURNAL ILMIAH ILMU PENDIDIKAN DAN SOSIAL, 9(3), 244251.

Sinambela, Lijan Poltak. 2017. Kinerja Pegawai: Teori Pengukuran dan Implikasi. Yogyakarta: Graha IImu.

Wahyuni, Sri. 2011. Analisis Balanced Scorecard sebagai Alat Pengukuran Kinerja pada PT. Semen Bosowa Maros. Skripsi. Universitas Hasanuddin. Makassar.

Welas. 2017. Analisis Kinerja Keungan dengan Pendekatan Sistem Du Pont (Studi Empirik pada Perusahaan Rokok yang Sudah Go Public Periode Tahun 20002004). Jurnal Akuntansi dan Keuangan. Vol. 1, No. 1. Halaman 58-71. 